\title{
9 \\ A Legacy beyond War and Peace
}

\section{A Peaceful Death}

Until 8 March 1951, Shidehara had been attending the Diet in his capacity as speaker of the House of Representatives. However, according to his secretary Kishi Kuramatsu, on 9 March he was unable to rise for breakfast. On 10 March, as evening fell upon Setagaya, Shidehara quietly took his last breath. He died peacefully of a heart attack at the age of $78 .{ }^{1}$ MacArthur promptly issued the following statement:

I wish to express my deepest condolences at the passing of House Speaker Shidehara. Mr. Shidehara's insight and expansive knowledge has been of great service to Japan on its journey to recovery. With world affairs in their current tense state, Mr. Shidehara's passing will certainly be a significant blow. ${ }^{2}$

Shidehara had helped to build an era in prewar Japan. After the war he served as prime minister during the occupation before assuming the position of speaker of the House of Representatives. Though he had once detested political parties, he eventually served as president of the Progressive Party. In time, Shidehara's disagreements with Ashida led him to leave the Democratic Party and form the Dōshi Club. He would subsequently bring his supporters with him to merge with Yoshida Shigeru's Liberal Party, and he became chief adviser to the Democratic Liberal Party. As the Democratic Liberal Party had joined with the 
coalition faction of the Democratic Party and established the Liberal Party, it was expected that the former Dōshi Club's faction would be weakened by Shidehara's passing. ${ }^{3}$

Ultimately, however, in Shidehara's career, it is his time as foreign minister that looms the largest. When he passed away, it was seen, more than anything, as the loss of the Japanese diplomatic world's eldest statesman. Former prime minister Ashida Hitoshi remarked: 'In my opinion, the big stage upon which Mr. Shidehara strode as a diplomat was, more than anything else, the Washington Naval Conference on Disarmament of 1922'. ${ }^{4}$ Similarly, President of the House of Councillors Satō Naotake immediately mentioned the London Naval Conference when discussing Shidehara's achievements. Satō added: 'Even at this age, I still cannot help but think of Shidehara as akin to my master; even in the Diet I was able to frankly ask for his advice.'

On 12 March, two days after Shidehara's passing, a farewell service was held at his residence in Okamoto, Setagaya ward. On that occasion, a copy of some English-language correspondence that had been found in his bedside box of papers was brought out. The letter was addressed 'Dear Mr. Grew'. Its intended recipient was the former US ambassador to Japan, Joseph Grew. Grew had once agreed to a request from Shidehara that he write a message of hope for the youth of Japan, whose nation was now devastated. In response, Shidehara had written in English the following expression of thanks:

May I thank you ever so much for your welcome letter of February 12, enclosing a message of encouragement to the youth of Japan? The message is as impressive as it is edifying, and exactly fits the need of the times. I have sent it to the Tokyo Shimbun (an influential Evening Daily) and the Nippon Times for publication.

The article immediately arrested the attention of the public. Numbers of people, both aged and young, have expressed to me verbally or in writing their profound appreciation of the communication. They have been moved by the singleness of heart and of purpose which has actuated the advice contained in your utterance. Emerging from the depth of misery into which they had been precipitated by the War, they are now beginning to find a way of hope ahead, enlightened by your inspiring word. ${ }^{6}$ 
Shidehara's correspondence to Grew was shared with the successive mourners of various walks of life who visited the residence on that day. According to the Tokyo Shimbun:

From this last piece of writing one has a sense of the friendship that [Shidehara] shared with Grew until his death, and of Mr. [Shidehara's] sympathy and hopes for the youth of Japan, whom he did not forget until the very end; it conveys to us a vision of the deceased. ${ }^{7}$

The mourners who paid their respects starting the day before included not only Prime Minister Yoshida but also Chamberlain Irie Sukemasa, who had been sent on behalf of the Shōwa emperor.

\section{A House of Representatives Funeral}

While a continuous stream of mourners visited the Shidehara residence for the farewell service, the House of Representatives-now missing its speaker-held a meeting of the Assembly Steering Committee. The topic of discussion was the holding of a state funeral, or, in this case, a 'House of Representatives funeral'. Until then there had only been three instances of a house speaker dying in office and none of them had a House of Representatives funeral. Indeed, for a precedent it was necessary to look instead to the passing of the president of the House of Councillors, Matsudaira Tsuneo. Matsudaira had died in office on 14 November 1949, and a 'House of Councillors funeral' was held the following day. Following this precedent, the committee decided to hold the first-ever House of Representatives funeral. The role of chairing the funeral organising committee went to the next speaker of the House of Representatives, while each of the Diet factions sent one person to assist as a committee member.

However, the ceremony differed from Matsudaira's in certain respects. While Matsudaira's House of Councillors funeral was held at the official residence of the president, this decision was unpopular due to the venue's small size. For Shidehara's funeral, even more mourners were expected. Taking into consideration matters such as the ongoing farewell service, it was decided to see if the funeral could be held at Tsukiji Honganji temple. After quickly confirming with the temple, it was determined that 16 March was the only full day available. ${ }^{8}$ Thus, Shidehara's House of Representatives funeral was held on 16 March at 1 pm at Tsukiji Honganji 
temple. The chairman of the ceremony was Hayashi Jojji. Hayashi had been promoted by Prime Minister Yoshida and had only just been elevated from deputy prime minister to speaker of the House of Representatives following Shidehara's passing. The House of Representatives itself was adjourned for the day as an expression of mourning. ${ }^{9}$

Of the many distinguished men who attended the funeral, the one who garnered particular attention was Shigemitsu Mamoru, still on parole following his release from prison, and who had been tasked on this occasion with burning the ceremonial incense. When the incense-burning was concluded, Speaker Hayashi and the heads of the three branches of government each gave their messages of condolence. These three individuals were Satō, president of the House of Councillors; Prime Minister Yoshida; and Tanaka Kōtarō, the chief justice of Japan. ${ }^{10}$

What were Shidehara's last words as speaker of the House of Representatives? His last official statement was an address to the plenary session of the House of Representatives, held on 6 March. There were over 10 items on the day's agenda, including the nomination of members for the National Capital Construction Committee. The item that generated the most debate was related to the securing of emergency imports following the outbreak of the Korean War. As it happened, Shidehara's last official words as recorded in the session minutes were quite ordinary: 'Those standing are the majority. Therefore, all three proposals have been passed in accordance with the chairman's report. This concludes today's agenda. The session is now adjourned'. ${ }^{11}$ Yet a close reading of the session minutes provides glimpses of Shidehara in his role as speaker, acting with his typical thoroughness. For example, when the Communist Party Diet member Kazahaya Yasoji opposed the resolution to secure emergency imports, Shidehara responded: 'If any inappropriate language has been used in Mr. Kazahaya's remarks, then I will take appropriate steps following an investigation of the stenographic records'.$^{12}$ Even during lengthy speeches, Shidehara did not let anything get past him; his mind remained as sharp as ever. This session took place on 6 March, only 10 days before the funeral.

After the plenary session for that day had ended, Shidehara headed towards the Imperial Palace together with the president of the House of Councillors, Satō Naotake. Satō later remarked: 
When we visited the palace together on March 6, which was Her Majesty the Empress's birthday, Mr. Shidehara quite easily consumed three or four of those red-lacquered cups worth of celebratory sake. I remember returning home and thinking to myself that he was still very much in good form. ${ }^{13}$

Satō continued:

When I first met Mr. Shidehara, I was still a student at Hitotsubashi Commercial College. Mr. Shidehara was living on the same road, near [the present-day] Nogi Shrine in Akasaka. In the middle of the Russo-Japanese War, Mr. Shidehara was the director of the Telegraph Division [sic.] of the Ministry of Foreign Affairs. As such, he was very busy. I was up late at night myself those days, preparing for the diplomatic service exam, so I would hear when he returned from the ministry on a two-horse carriage. I still remember the sound of the driver's voice as he called out 'Welcome home' whenever they arrived. ${ }^{14}$

Satō also remarked that:

It was surprising just how much he read. He also had a remarkable encyclopedic knowledge ... I would frequently go to speak with him, and Mr. Shidehara would also sometimes casually drop by the president's office to pay me a visit. ${ }^{15}$

We have seen that Shidehara was in good health until just before his death. He had spent the coming of the new year of 1951 at his villa in the village of Kotsubo, in the Zushi region south of Yokohama. Shidehara would look forward to visits from old friends, and when guests arrived, he enjoyed regaling them with stories. He was always particularly talkative concerning the framed calligraphy of Saionji Kinmochi, which stated: 'Shūen Villa' (聚遠荘, Shūen-sō). Saionji's brushstrokes had an air of dignity about it. Those guests visiting the villa:

Were able to entirely forget the outside world and the wretched state it was in. Even the passing of time would go unnoticed while they were enthralled by Shidehara's skillfully delivered stories. ${ }^{16}$

As he loquaciously spoke with his guests, Shidehara likely had little idea that his life was now nearing its end.

To identify Shidehara's last actions in the realm of diplomatic affairs, we need to return to when Dulles visited Japan in June 1950. At that time, Shidehara elaborated upon his long-held view that diplomacy ought 
to be kept separate from a nation's domestic politics. He would speak with a number of individuals in an effort to convince them of the need for nonpartisan diplomacy, including not only Prime Minister Yoshida but also opposition figures such as Tomabechi Gizō and Asanuma Inejirō. The Yomiuri Shimbun noted: 'It seemed as though Mr. Shidehara believed this work would be his last "public service" as the eldest statesman of [Japan's] diplomatic world'. ${ }^{17}$ A Japanese saying notes 'the tenacity of old age'. Certainly, Shidehara was the very embodiment of this saying when it came to his efforts in those days.

\section{Reactions, Domestic and Abroad}

There is another saying in Japanese: it is only when the coffin is sealed that a person's worth can be assessed. Shidehara had continuously received both praise and censure while he was alive. But what did the various newspapers have to say after his passing? Of the editorials that appeared in the three major Japanese papers, the one with the most favourable assessment of Shidehara and his legacy was from the Mainichi Shimbun. This 11 March 1951, editorial stated:

We had only recently lost another elder statesman of the nation's diplomatic world-Matsudaira, president of the House of Representatives. After all is said and done, however, Mr. Shidehara did not merely stand at the very peak of his field as it currently stands. As indicated by the term 'Shidehara diplomacy,' he also left a significant mark upon the landscape of Japan's diplomatic history in the form of his own systematic approach. Frankly, if Japanese diplomacy had proceeded along the course indicated by Mr. Shidehara, then this nation may well have managed to avoid ending up in its current miserable state. If we contemplate the fact that there is neither a 'Yoshida diplomacy' nor a 'Matsudaira diplomacy' but that there was a 'Shidehara diplomacy,' then we may be able to appreciate that we have lost more than merely the eldest statesman of that world. ${ }^{18}$

Meanwhile, although the 12 March editorial in the Yomiuri Shimbun praised Shidehara for his diplomatic efforts, it was quite harsh in critiquing his insufficient self-awareness as a politician:

Mr. Shidehara's political and diplomatic contributions to our nation may be numerous. Yet what draws our attention above all is the manner in which he took charge of an extremely difficult 
situation following the loss of the war, while at the same time bringing about the establishment of a 'new constitution' that is unprecedented worldwide in its intelligence and cultural refinement ... When compared with his achievements as a diplomat, which were so significant that he actually defined a new era with his 'Shidehara diplomacy,' his work as a party politician, it must be admitted, was entirely ordinary ... That Mr. Shidehara was more an individualist than a party man must be looked upon with some regret from the perspective of the development of our nation's party politics. ${ }^{19}$

Then there was the 11 March editorial of the Asahi Shimbun, which even attacked Shidehara's stance as a diplomat:

Mr. Shidehara was the very incarnation of a bureaucratic diplomat. He devoted his long life to diplomacy, and his achievements ought to be highly praised by the nation's citizens. However, now that Japan has been reborn as a democratic country, it is necessary to find a way towards a new national diplomacy. For this purpose, we must find new leaders of national diplomacy who can help show us the way forward. ${ }^{20}$

Although the Asahi Shimbun editorial recognised Shidehara's achievements as a 'bureaucratic diplomat', it looked forward to the coming of 'new leaders of national diplomacy', ones more suited to the democratic currents of the postwar era.

It should be remembered that Shidehara once made a name for himself on the international stage as well. It is worth examining how his passing was covered in the foreign press. First, let us look at the New York Times. An article on Shidehara's death, accompanied by a photograph, appeared in this paper on 11 March. It stated that Shidehara was 'among the few Japanese leaders who really understood the Western mind' and that he had spent his final few months helping with preparations for the coming peace settlement. This article was followed by another that served as a kind of corroboration. It was a message of condolence from Dulles. Having just returned from his visit to Japan, Dulles noted that he had 'met often with Mr. Shidehara and came personally to appreciate [his] liberal and anti-militarist spirit'. ${ }^{21}$

The Washington Post also included an obituary with a photograph on that day. Later, on 13 March, the paper ran a sympathetic piece on Shidehara's difficulties as foreign minister during the Manchurian Incident. A similar 
view was expressed in a 21 March letter to the editor by former US ambassador to Japan Joseph Grew. In it, Grew looked back on the period following the Russo-Japanese War, and the friendship between Shidehara and ministry adviser Denison. According to Grew, a young Shidehara had diligently studied international law under Denison while also polishing his English. Denison responded to this show of dedication, eventually bequeathing him 35 years' worth of diary entries and records of his official duties. Shidehara had also frequently written of Denison in his own diary. Tragically, both Shidehara's and Denison's diaries were destroyed in the bombing of Tokyo. As Grew recounted these anecdotes for the newspaper, he may well have been fondly reminiscing about the 'good old days' of Japan-US relations.

Grew was not the only one to pick up his pen upon seeing Shidehara's obituary. Another letter to the editor appeared in the Washington Post on 25 March, this time from Castle. Castle, it may be recalled, had served as US ambassador to Japan during the London Naval Conference on Disarmament. In his letter, he noted how impressed he had been by Shidehara's discernment. He further acknowledged that he had learned a great deal from Shidehara on the topic of China policy following the Northern Expedition. Castle concluded by noting that, in a postwar Japan where civil servants were now in control of politics, 'the influence of Shidehara will not die with him'. ${ }^{22}$

\section{The San Francisco Peace Treaty and Shidehara's Legacy}

History is concerned with facts, not counterfactuals. Yet it is hard not to wonder what might have happened if Shidehara had lived an extra halfyear. For it was during this time that the San Francisco Peace Conference took place. In the newspapers published in Japan on 10 March 1951-the day of Shidehara's death-articles on Dulles made the front page. Having concluded his five-week tour of the Far East, Special Envoy Dulles had sent a report to the diplomatic committee of the US Senate. Dulles sought to obtain the support of the committee with an eye to bringing about an early conclusion to the peace accord negotiations with Japan. At the same time, Dulles had been making progress with a draft of the peace treaty itself, while taking pains not to forbid Japan from rearming. 
However, it was not only the US that needed to be convinced. Australia had shown some resistance to the idea of signing a peace treaty permitting Japan's rearmament if there was no guarantee of a mutual defence treaty. In fact, the ANZUS treaty, signed later that year by Australia, New Zealand and the US, was just such a treaty. Nations such as the Philippines had also reacted negatively to Dulles's policy of not requesting Japan to pay reparations. The UK, meanwhile, apprehensive of a return to competing with Japan in the areas of shipping and textiles, sought a treaty that would limit the nation's economic activities. Then there was Yakov Aleksandrovich Malik, representative for the Soviet Union. Malik had told Dulles he would not even negotiate with him about a peace treaty with Japan. ${ }^{23}$

As a foreign minister, Shidehara had made a name for himself internationally. During the occupation, he had served as prime minister, and, at the time of his passing, he was still active as the speaker for the House of Representatives. If he had lived a little longer, therefore, he might have been a strong candidate as the plenipotentiary for Japan at the San Francisco Peace Conference. Indeed, the Yomiuri Shimbun noted that 'there was word Prime Minister Yoshida had sought to make Mr. Shidehara the peace plenipotentiary'. ${ }^{24}$ After all, until just before his death, Shidehara remained healthy enough that he was still attending the House sessions.

Of course, as the Asahi Shimbun editorial pointed out, it was no longer the age of the 'bureaucratic diplomat'. Likewise, Shidehara struggled in his attempts at promoting nonpartisan diplomacy. Yoshida Shigeru, who, like Shidehara, was a former diplomat, would also struggle politically following the conclusion of the peace treaty. Yoshida had to deal with difficult problems such as rearmament; however, more fundamentally, he may have been unsuited to party politics. This was a time when 'leaders of national diplomacy' were desired, and Yoshida was a poor retail politician. He was also not the type to give speeches in public venues.

In many cases, the key to diplomacy in postwar Japan was the leadership of the prime minister. A fitting example was Prime Minister Hatoyama Ichirō's visit to the Soviet Union, which succeeded in normalising JapanSoviet relations. The foreign minister in the Hatoyama cabinet was Shigemitsu Mamoru. As a member of the generation after Shidehara's, Shigemitsu was a representative diplomat of the Shōwa era. By contrast, Prime Minister Hatoyama was a party politician. As such, he was hardly 
likely to be as familiar with the practice of diplomacy as Shigemitsu. Nevertheless, it was Hatoyama's visit to the Soviet Union that secured the restoration of diplomatic relations. Simply put, it was Prime Minister Hatoyama who signed the Japan-Soviet Joint Declaration, not Foreign Minister Shigemitsu.

Other examples of diplomatic initiatives that were led by Japan's prime ministers include the amendment of the US-Japan Security Treaty carried out under Kishi Nobusuke, the reversion of Okinawa to Japan under Satō $E^{E i s a k u}{ }^{25}$ and the normalisation of the Sino-Japanese diplomatic relations under Tanaka Kakuei. ${ }^{26}$ While Foreign Ministry diplomats had never received a great deal of attention, now even the foreign minister himself was increasingly becoming eclipsed. That said, prime ministers such as Kishi Nobusuke, Ikeda Hayato, Satō Eisaku, Fukuda Takeo and Ōhira Masayoshi were all originally bureaucrats. The difference was that their shared background was in economics rather than diplomacy.

Following the signing of the Treaty of San Francisco, Japanese diplomacy increasingly moved away from the ideals once promoted by Shideharathose of centralisation under the Ministry of Foreign Affairs and nonpartisan diplomacy. That said, history is often full of ironies. It was under the occupation that former diplomats such as Shidehara, Yoshida and Ashida rose to the rank of prime minister. Even the posts of speaker and president of the two houses of the Diet were occupied by former diplomatic officials such as Shidehara, Matsudaira Tsuneo and Satō Naotake. However, once Japan regained its sovereignty, the authority of the Ministry of Foreign Affairs, its 'supreme power' over diplomatic affairs, appeared to wane. With his passing, only half a year before the conclusion of the peace treaty, it was almost as if Shidehara was alluding to this changing of the times. Most likely, there will never again be a figure whose own fate embodies the rise and fall of the Ministry of Foreign Affairs to the extent that Shidehara's did.

\section{Endnotes}

1 Asahi Shimbun, 11 March 1951. See also Hirano Saburō, Heiwa Kenpō Hiwa: Shidehara Kijūrō Sono Hito to Shisō [The secret story of the peace constitution: Shidehara Kijūrō, the man and his thought] (Tokyo: Kōdansha, 1972), 53; Shidehara Peace Foundation, Shidehara Kijūrō, 767-85. For further information on Kishi Kuramatsu, see Kajima Peace Research Center, ed., Kaisō no Senji Gaikō [Reflections on wartime diplomacy] (Tokyo: Bensei Shuppan, 2003), 67. This chapter is based on my previous work: Hattori Ryūji, 'Shidehara Botsugo' [After the death of Shidehara], Söbun, no. 454 (June 2003): 16-20.

2 Mainichi Shimbun, 11 March 1951. 
3 Ibid.

4 Asahi Shimbun, 11 March 1951.

5 Mainichi Shimbun, 11 March 1951.

6 Shidehara to Grew, 2 March 1951, in 'Shidehara Heiwa Bunko', Reel 17. This English correspondence was also translated into Japanese and printed in the Tokyo Shimbun, 13 March 1951.

7 Tokyo Shimbun, 13 March 1951.

8 'Dai Jukkai Kokkai Shūgiin Giin Unei Iinkai Giroku' [10th Diet House of Representatives Diet Operation Committee Minutes], no. 25, 20 March 1951.

9 'Zen-Gichō Shidehara Kijūrō-kun Shūgiin So Shikkō nitsuki Aitō no I wo Arawasuru tame Kyūkai Suru Koto wo Giketsu no Ken' [Matter of the resolution to adjourn in order to express our grief on the occasion of the House of Representatives funeral of former speaker of the House of Representatives Shidehara Kijūrō], 13 March 1951, 1-2A-028-04-rui-03527-100, National Archives of Japan.

10 Asahi Shimbun, 17 March 1951.

11 Kanpō, extra edition, 7 March 1951.

12 Ibid.

13 Satō Naotake, 'Shidehara-san wo Itamu' [Mourning Mr Shidehara], Shūkan Asahi 56, no. 12 (March 1951): 41.

14 Ibid.

15 Ibid.

16 Satō Junzō, 'Shidehara-san to Nihon-tō' [Mr Shidehara and the Japanese sword], Kasumigasekikai Kaihō, no. 179 (January 1961): 11-12.

17 Yomiuri Shimbun, 11 March 1951.

18 Mainichi Shimbun, 11 March 1951.

19 Yomiuri Shimbun, 12 March 1951.

20 Asahi Shimbun, 11 March 1951.

21 New York Times, 11 March 1951.

22 Washington Post, 11, 13, 21, 25 March 1951. A part was reprinted in Joseph C. Grew, 'Shidehara Kijūrō wo Itamu’ [Mourning Shidehara Kijūrō], Kaizō 32, no. 6 (May 1951): 70-71.

23 Asahi Shimbun, 10 March 1951.

24 Yomiuri Shimbun, 11 March 1951.

25 Hattori Ryūji, Eisaku Satō, Japanese Prime Minister, 1964-72: Okinawa, Foreign Relations, Domestic Politics and the Nobel Prize, trans. Graham B. Leonard (London: Routledge, 2021), 150-204, doi.org/10.4324/9781003083306.

26 Hattori Ryūji, Nicchū Kokkō Seijōka: Tanaka Kakuei, Ōhira Masayoshi, Kanryō Tachi no Chōsen [The normalization of diplomatic relations between Japan and China: Tanaka Kakuei, Ohira Masayoshi, and bureaucrats' challenge] (Tokyo: Chūo Kōron Shinsha, 2011), 51-208. See also Hattori Ryūji, Understanding History in Asia: What Diplomatic Documents Reveal, trans. Tara Cannon (Tokyo: Japan Publish Industry Foundation for Culture, 2019), 23-28. 
This text is taken from Japan at War and Peace: Shidehara Kijürō and the Making of Modern Diplomacy, by Ryuji Hattori, published 2021 by ANU Press, The Australian National University, Canberra, Australia.

doi.org/10.22459/JWP.2021.09 